\title{
Etiology of Retinal and Cerebellar Pathology in Western Pacific Amyotrophic Lateral Sclerosis and Parkinsonism-Dementia Complex
}

This article was published in the following Dove Press journal: Eye and Brain

\section{Peter S Spencer (iD}

Department of Neurology, School of Medicine, Oregon Institute of Occupational Health Sciences, Oregon Health \& Science University, Portland, OR, USA
Correspondence: Peter S Spencer

Oregon Health \& Science University, 3|8I

SW Sam Jackson Park Road, Portland, OR 97239

Tel + I 503 209-0986

Email spencer@ohsu.edu
Purpose: To reexamine the etiology of a unique retinal pathology (linear and vermiform sub-retinal tubular structures) described among subjects with and without neurodegenerative disease in former high-incidence foci of Western Pacific amyotrophic lateral sclerosis and parkinsonism-dementia complex (ALS/PDC) in Guam (USA) and the Kii peninsula of Honshu island (Japan).

Methods: Analysis of published and unpublished reports of 1) ALS/PDC and the retinal and cerebellar pathology associated therewith and 2) exogenous neurotoxic factors associated with ALS/PDC and the developing retina and cerebellum.

Results: ALS/PDC retinal and cerebellar pathology matches persistent retinal and cerebellar dysplasia found in laboratory animals given single in utero or postnatal systemic treatment with cycasin, the principal neurotoxic component in the seed of cycad plants traditionally used for food (Guam) or oral medicine (Kii-Japan), both of which have been linked to the human neurodegenerative disease.

Conclusion: ALS/PDC-associated retinal and cerebellar dysplasia could arise from in utero exposure to methylazoxymethanol, the genotoxic metabolite of cycasin that results from maternal ingestion of this azoxyglucoside. These results support the environmental toxic etiology of retinal and brain pathology in ALS/PDC.

Keywords: amyotrophic lateral sclerosis, cycad, DNA damage, Guam, methylazoxymethanol, photoreceptor, retinal development, retinal dysplasia, retinal epitheliopathy, rosettes

\section{Introduction}

Unique sub-retinal, depigmented, focal, linear or vermiform structures have been reported in Western Pacific amyotrophic lateral sclerosis and parkinsonism-dementia complex (ALS/PDC), a disappearing apparently environmental neurodegenerative disorder of Chamorros and others on Guam and of Japanese residents of the Kii peninsula of Honshu island, Japan. While of special interest to ophthalmologists, understanding the cause of the retinal pathology may also help illuminate the etiology of Western Pacific ALS/PDC, a prototypical neurodegenerative disease that may itself hold the keys to understanding the etiology of related brain disorders.

In 1971-73, a linear retinopathy was discovered in 35 Guamanians aged $>25$ years. The condition was thought to resemble ophthalmomyiasis interna (OMI), which results from the parasitic activity of an intraocular botfly larva. ${ }^{1,2}$ Retinopathy was found in 53\% (38 of 72) of Guamanians with ALS/PDC and 16\% (85 of 531) of those who were neurologically normal at the time of examination; these findings were later independently 
confirmed. $^{3-6}$ Described by North American investigators as "Guam Linear Retinal Pigment Epitheliopathy (LRPE)", the 50-200 micrometer-wide tracks occurred in one or both eyes [Figure 1, left], remained unchanged over observation periods of up to 24 years, were statistically associated with ALS/PDC and observed to precede the onset of clinical neurological disease by 1-19 years. The tracks of LRPE involved the whole of the fundus or were limited to a small area. Sometimes they involved the macula but without any impairment of vision. While LRPE was remarkably prevalent in the native Chamorro people of Guam born before 1957 and also observed in a Filipino immigrant to Guam, by 2008, the retinopathy was absent in young and middle-aged Guamanians (J.C. Steele, personal communication).

In 2003, the same type of OMI-like linear retinopathy was described in Kii ALS/PDC. ${ }^{7}$ A subsequent study of 12 Japanese patients with ALS/PDC ( 7 men and 5 women, mean age 64.3 years) revealed a pigmentary retinopathy in $33 \%$ (4 of 12) and in 1 of 115 healthy residents (aged 20-89 years). ${ }^{8,9}$ The Japanese group stated that the cause of the pigmentary retinopathy was unclear but that the condition differed from ophthalmomyiasis interna.

Although LPRE has been considered evidence of an infective agent operating in ALS/PDC, an intraocular organism has never been identified. Parasitic Oestridae (botflies) larvae were excluded based on the subretinal location, diameter and lack of inflammation associated with the "larval tracks", coupled with the absence of any history of eye discomfort caused by injection of a botfly egg into the human eye. Moreover, recent videography of a subretinal botfly larva shows no evidence of retinal tracks, ${ }^{10}$ and the serpentine movements of the living organism are inconsistent with the formation thereof. A blood-borne nematode larva migrans was also postulated by North American investigators, but patients neither recalled any symptoms of a cutaneous infection nor was there evidence of an inflammatory response either systemically or locally in association with the retinal tracks. ${ }^{11}$

An alternative explanation, proposed here for the first time, is that the retinal tracks seen in Guamanian and Japanese subjects with and without clinical ALS/PDC resulted from persistent focal or multifocal disorganization of the sensory retina arising during development. ${ }^{12}$ The pathogenesis of retinal dysplasia is a perturbation in the separation of the retina during a critical stage of differentiation of the underlying pigment epithelium. Examination of the adult retina with developmental dysplasia reveals multiple, linear, vermiform, tube-like structures that have a rosette-like structure in cross-section. A rosette represents an attempt to form embryonic retinal tissue rods and cones. The cells lining the rosette are analogous to the nuclei in the outer limiting membrane of the retina. ${ }^{13}$ Importantly, the tube-like structures caused by retinal dysplasia are similar if not identical to the ALS/PDC-associated tracks described as LRPE (Figure 1). Moreover, the principal neurotoxic agent (cycasin) in cycad seed, which is strongly implicated in the etiology of Western Pacific ALS/PDC, is an established cause of experimental retinal dysplasia during the development of multiple vertebrate species.

\section{Etiology of Retinal Pathology}

Cycad seed is the only common exposure factor that links ALS/PDC in Guam, Kii-Japan and a third focus in Papua, Indonesia $^{15}$ where ophthalmological examination of affected subjects has not been carried out. In the past, raw cycad seed was used to prepare an oral medicine and tonic in Kii-Japan and served as a topical medicine in Guam and Papua-Indonesia. ${ }^{15}$ On Guam, the cycad seed cover was also used to quench thirst in the forest and dried to make a confection, and the washed but incompletely detoxified gametophyte was made into a flour used as a staple to prepare bread and soup. ${ }^{15}$ After the privations of the Second World War and with the postWar modernization of Guam and Japan, these traditional practices progressively declined and disappeared, as did the extraordinarily high post-War incidence of ALS/ PDC. ${ }^{16}$

The varied traditional uses of cycad seed resulted in exposure to cycad neurotoxins, principally cycasin, the active component of which is the genotoxic and antimitotic agent methylazoxymethanol (MAM) ${ }^{17}$ and, to a lesser extent, beta- $N$-methylamino-L-alanine (L-BMAA), which

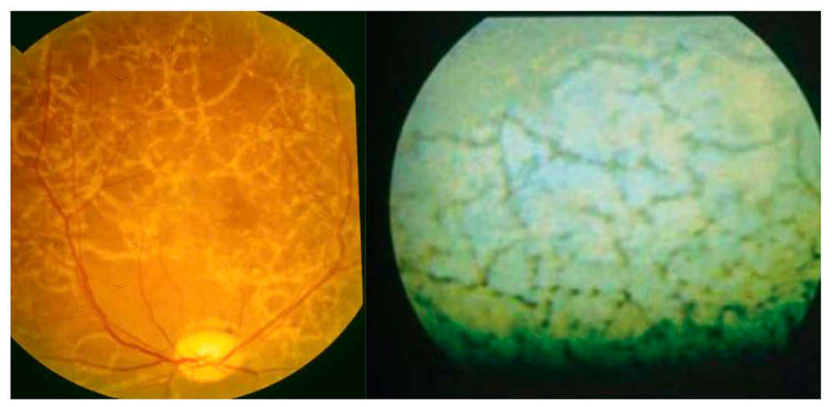

Figure I Fundoscopic images of human (Guam) linear pigmentary epitheliopathy (left, courtesy of Dr John Steele) and, by comparison (right), retinal dysplasia in a foal. Reproduced with permission from Ramsey DT, Ewart SL, Render JA, Cook CS, Latimer CA. Congenital ocular abnormalities of Rocky Mountain Horses. Vet Ophthalmol. 1999;2(I):47-59. Wiley. ${ }^{14}$ 
binds to melanin and induces retinal damage after intravitreal injection of young adult mice. ${ }^{18,19}$ The historical incidence of ALS/PDC among Chamorros on Guam is strongly linked to the cycasin (but not the L-BMAA) content of flour derived from cycad seed. ${ }^{20,21}$

MAM was shown experimentally to induce photoreceptor degeneration in the developing retina of laboratory animals over 50 years ago. ${ }^{22,23}$ MAM methylates nucleic acids and proteins in vivo and thereby kills dividing neuroblasts rapidly, ${ }^{23,24}$ perhaps in their final division phase. ${ }^{25-27}$ The experimental response to a single systemic dose of cycasin or MAM, which can include cerebral, cerebellar and retinal dysplasia, is critically dependent on the developmental stage at the time of administration, as well as the species and dosage. ${ }^{28-31}$ Susceptible species include hamsters, mice, rats, rabbits, ferrets, cats and beagles. ${ }^{31}$ The rat retina is susceptible to systemic MAM between days E17 and PE5. ${ }^{32}$ Pathological changes post-MAM treatment begin at 2 days and damaged cells are quickly removed by phagocytosis. The neuroblastic layer folds to produce tubular structures that appear as rosettes in cross-section. ${ }^{28}$ The earliest rosette appears 2-3 days post-MAM treatment. ${ }^{32}$ Animals injected postnatally and examined at 5 months of age show retinal dysplasia similar in character and distribution to animals examined at 3-4 weeks of age. ${ }^{28}$ Indeed, a single injection of the neurotoxin MAM (as the acetate) administered during certain critical perinatal periods results in permanent dysplasia of retinal cytoarchitecture. ${ }^{26}$ While there are no fundus photographs of MAM-induced retinal dysplasia in experimental species, the pathology is very familiar in veterinary practice where retinal dysplasia takes the form of unilateral or bilateral linear and vermiform tubular structures (comparable to LRPE) that appear as rosettes in cross-section [Figure 2]. Thus, a rosette represents an attempt to form embryonic retinal rods and cones. The lumen of each rosette contains elongated cell processes that signify abortive attempts toward rod and cone formation. The outer margin of the lumen of each rosette is lined by a membrane analogous to the external limiting membrane of the retina.

\section{Cerebellar and Retinal Dysplasia}

The developing cerebellum of rodents and other species is also susceptible to single systemic treatment with MAM acetate early in the postnatal period, such that retinal and cerebellar dysplasia often occur together ${ }^{31,34-36}$ [Figure 3]. The pathology involves MAM-induced formation of $O^{6}$ methylguanine $\left(O^{6}-\mathrm{mG}\right)$ DNA adducts that are normally

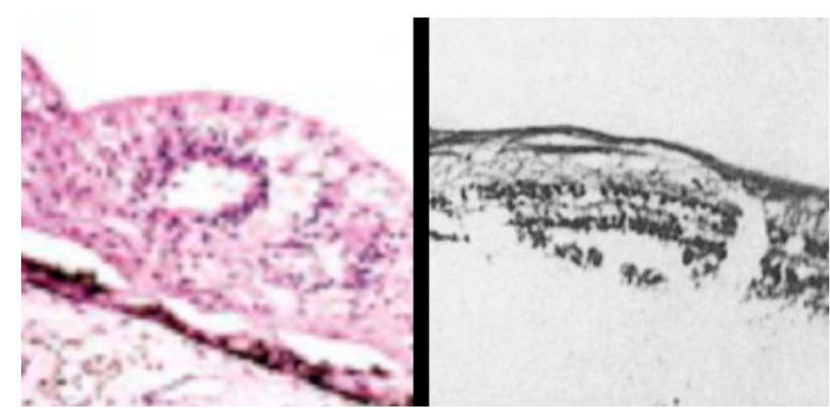

Figure 2 Left: Cross-section of a rosette in the retina of a foal. Paraffin section stained with hematoxylin and eosin (H\&E). Reprinted from Equine Ophthalmology, 2nd ed, Wilke DA, Disease of the ocular posterior segment, In: Gilger BC, editor, Copyright (20II), with permission from Elsevier. ${ }^{33}$ Right: A comparable retinal structure in a H\&E-stained section of the left eye of a LRPEpositive 56-year-old male with a 9-year history of Parkinsonism-dementia and normal left pupil, visual field, electrooculography and electroretinography. Reprinted from Ophthalmology, 100, Campbell RJ, Steele JC, Cox TA, et al. Pathological findings in the retinal pigment epitheliopathy associated with the amyotrophic lateral sclerosis/parkinsonism-dementia complex of Guam, 3742, copyright (1993), with permission from Elsevier. ${ }^{4}$ Eyes fixed 18 hours postmortem in 10\% normal-buffered formalin. Rosette pathogenesis appears to arise from abnormal histogenesis of the pigment epithelium.

repaired by $\mathrm{O}^{6}-\mathrm{mG}$ methyltransferase (MGMT), a suicide DNA-repair enzyme that transfers the methyl group from $O^{6}-\mathrm{mG}$ to its active-site cysteine residue and is subsequently targeted for degradation. ${ }^{37}$ Whereas transgenic mice lacking MGMT show increased susceptibility to MAM, mice overexpressing MGMT or negative for the gene coding for Aag DNA glycosylase are markedly protected from the cerebellar damage. ${ }^{38}$ Following attack of the mouse retina by a DNA alkylating agent, the enzyme Aag DNA glycosylase removes alkylated bases via cleavage of the glycosyl bond connecting the base to the sugar phosphate backbone, thus generating abasic sites that can be further processed by the base excision repair machinery. ${ }^{39}$

Since cellular migration is an important component of cerebellar development, the disruptive effects of MAM acetate result in tissue disorganization featured by ectopic and displaced Purkinje and granule cells. ${ }^{40-42}$ Administered at birth, MAM acetate perturbs cerebellar development in rodents [Figure 4], such that, at 21 days of age, granule cells are mixed with Purkinje neurons instead of forming layers. ${ }^{41,43}$ Importantly, some adult-onset Japanese and Guamanian ALS/PDC cases were reported (45 years ago) to have multinucleated and ectopic Purkinje-like neurons in the cerebellum and vestibular nuclei that were consistent with perturbed neurodevelopment. ${ }^{44}$ These long-neglected findings were confirmed in a 2018 neuropathological study of the cerebellum of 10 male and female Kii ALS/PDC cases (aged 

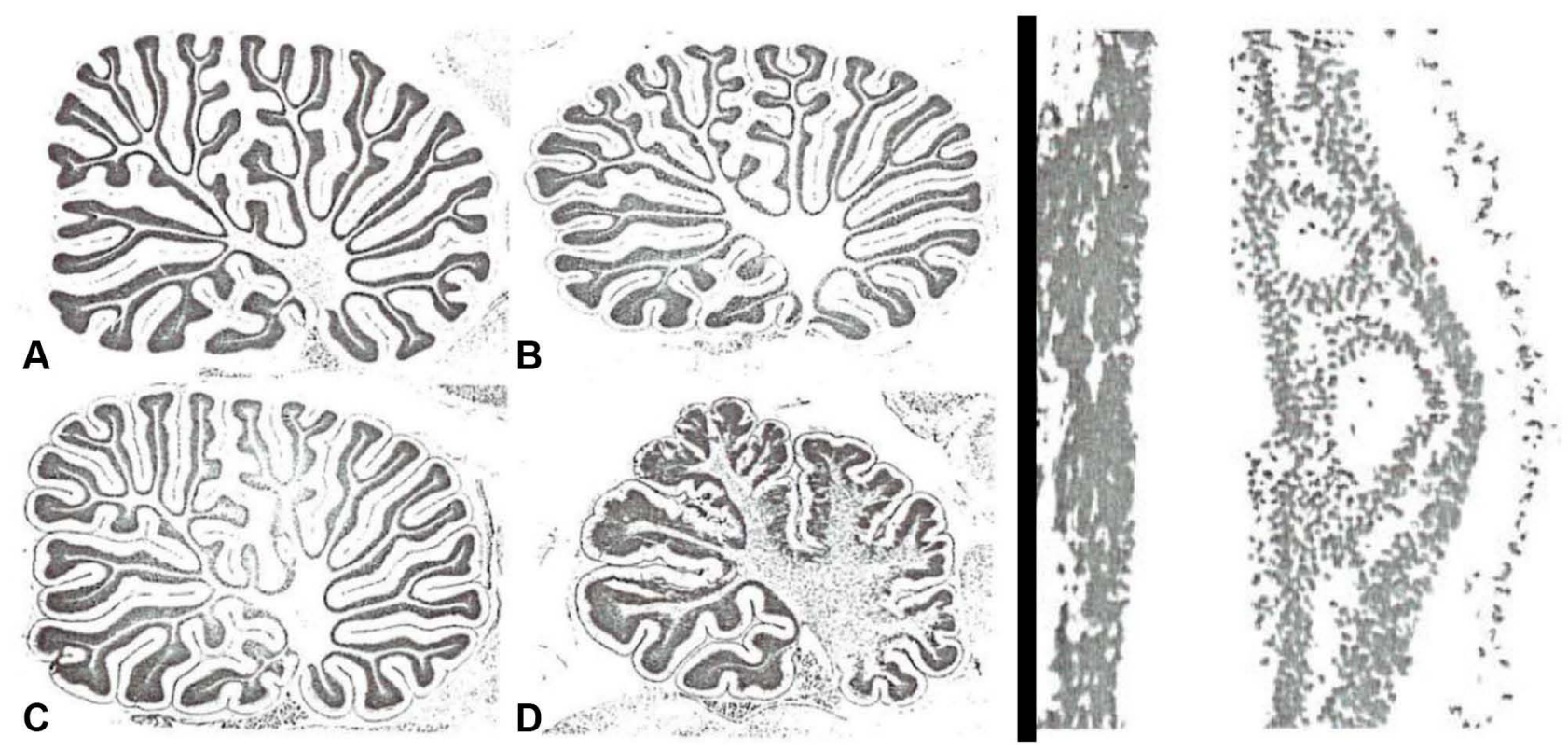

Figure 3 Left: Six-week-old ferret cerebellum. (A) Normal. (B) Systemically treated with a single dose of I5 mg/kg methylazoxymethanol (MAM) on gestation day (GD) 27. (C) Treated with MAM on GD 32. (D) Treated with MAM on GD40 (dysplasia). (B-D) Abnormal persistence of the external granular layers. Near-midline parasagittal paraffin sections stained with cresyl violet. Right: Ferret retina. Rosettes observed unilaterally or bilaterally after systemic treatment with MAM on GD32. Copyright @ I 980. Springer. Adapted from Haddad R, Rabe A. Use of the ferret in experimental neuroteratology: cerebral, cerebellar, and retinal dysplasias. In: Persaud TVN, editor. Neural and Behavioural Teratology Baltimore: Advances in the Study of Birth Defects. Vol. 4. Uni Park Press; 1980:45-62. ${ }^{31}$

63-77 years), all of whom had no clinical cerebellar signs. ${ }^{45}$ Cases but not age-matched controls had dislocated and multinucleated Purkinje cells in the molecular layer, pathological changes in the dentate nucleus and cerebellum, the latter characterized by $3 R$ and $4 R$ tau pathology. The retina of these cases was not examined.

\section{Discussion}

There is compelling negative evidence to question the hypothesis that a botfly larva or larval migrans is responsible for the retinal tracts found on fundus examination of Guam and Japanese subjects with or without clinical ALS/ PDC, a disappearing long-latency environmental neurodegenerative disease linked etiologically to cycad exposure and, in particular to cycasin. By contrast, there is overwhelming evidence from controlled studies of laboratory mammals that systemic perinatal treatment with cycasin or the acetate of its aglycone MAM induces cerebellar and retinal dysplasia, with cerebellar disorganization and retinal tubular structures resembling those reported in ALS/ PDC. The histology of the retinal pathology (described as LRPE) in ALS/PDC has been published in only one instance, ${ }^{4}$ in which one of the two sections illustrated appears to show a rosette (Figure 2, right). Clearly, it will be important to re-examine the retina of ALS/PDC cases in which cerebellar dysplasia is evident to determine the presence of retinal rosettes as predicted here from longstanding experimental data.

The question arises as to the timing, method and amount of exposure to cycasin-MAM that could explain developmental retinal and cerebellar dysplasia in Guamanian and Japanese subjects. For human cerebellar ontogenesis, Purkinje cells are formed in the ventricular zone early in embryonic life and, between the 9th and 13th gestational week, start to migrate radially directly to their definitive cortical sites where, at the 28th week of gestation, they develop structural and functional associations with arriving climbing fibers. Granule cell precursors migrate tangentially along the cerebellar surface to form a transient external granular layer at 10-11 gestational weeks, then postnatally migrate inward through the molecular layer to form the internal granule layer. ${ }^{46}$ Migrating granule and Purkinje cells are therefore at risk for MAM-induced disruption from the 2nd trimester onwards. Similarly, since the retina of the rat at birth is equivalent in the developmental stage to the human retina at $4-5$ months of gestation, ${ }^{12}$ this implies that retinal dysplasia in humans can be acquired during fetal development and specifically during the second trimester. Since ingested cycasin gives rise to MAM in the gut and MAM crosses the placenta (and enters mother's milk), a second-to-third trimester pregnant Guamanian or Japanese 

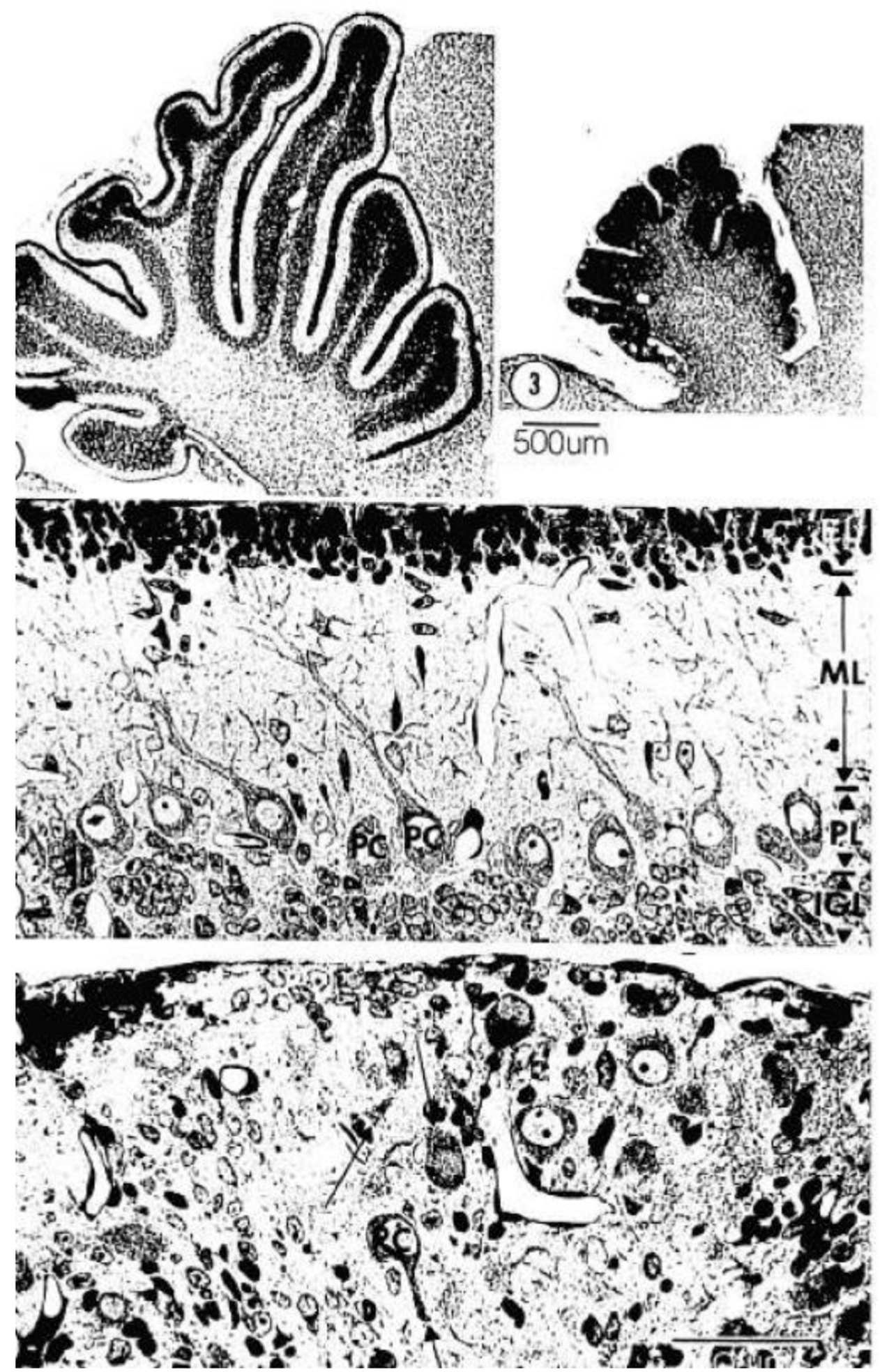

Figure 4 Top Left: Normal arrangement of the newborn Swiss albino mouse cerebellar vermis on postnatal day (PND) I0. Top Right: PND-10 mouse systemically treated at birth with 0.05 microliter/g body weight methylazoxymethanol (MAM). Center and Lower: Randomly located Purkinje cell somata [PC] are located in the molecular and attenuated internal granule cell layers (arising from MAM-induced cell death and failed cell migration). EL, external differentiating cell; ML, molecular layer; PL, Purkinje cell layer; IGL, internal granule cell layer. Tissue fixed by immersion in $10 \%$ buffered formalin, embedded in paraffin and sections stained with H\&E (top) or phosphate-buffered $2 \%$ osmium tetroxide, embedded in epoxy resin, with sections stained with toluidine blue-stained (center and lower). Hartkop TH, Jones MZ. Methylazoxymethanolinduced aberrant Purkinje cell dendritic development. J Neuropathol Exp Neurol. 1977:36:519-532, permission of Oxford University Press. ${ }^{42}$ 
women exposed orally to cycasin in food (Guam) ${ }^{47}$ or medicine/tonic (Kii-Japan) ${ }^{48}$ would be at risk for induction of fetal retinal and cerebellar dysplasia, evidence of which would persist throughout adult life. Additionally, if the mother's exposure to cycad toxins was sufficient to trigger ALS/PDC, clinical evidence of this long-latency disorder would appear years or decades later. Unknown are the toxic thresholds that must be exceeded to activate the pathogenesis of either progressive neurodegenerative disease in adults or retinal and cerebellar dysplasia during development.

There is evidence that the retinal tracks in clinically normal Guamanians not only pre-date but also sometimes predict the later development of clinical ALS/PDC. Steele followed 17 of 28 Chamorro subjects (34-65 years old) who had been diagnosed between 1982 and 1984 with presumed ophthalmomyiasis interna by US Navy ophthalmologist Donald Digby. All were neurologically asymptomatic at the time of diagnosis, except one who was in the early stages of PDC. During the intervening 26 years, 10 others developed PDC, 3 to 22 years after the retinal tracks had been recognized. ${ }^{11}$

While the present evidence suggests that retinal tracks were acquired developmentally, this does not necessarily indicate that the trigger for ALS/PDC was contemporaneous. Rather, it suggests that subjects with cycadassociated developmental retinal pathology grew up and functioned in a family and culture in which cycad products were used orally for medicine (Japan) and food (Guam). Epidemiological evidence demonstrates that residency in a Chamorro household on Guam during childhood and adolescence through age 18 years was required for susceptibility to ALS appearing clinically 1-34 years later, ${ }^{49}$ and picking processing and eating cycad products between the ages of 20 and 40 was associated with PDC, ${ }^{21}$ a traditional Chamorro practice that progressively disappeared after World War II. During a similar period, Japanese folk medicine practitioners (kitoshi) who prescribed cycad seed for various ailments (tuberculosis, dysmenorrhea, digestion problems) and to effect abortion were gradually replaced by modern medical practitioners. ${ }^{48}$ Taken together, the progressive reduction of cycad exposure accounts for the decline and disappearance of ALS/PDC and associated retinal pathology.

While the seed of cycad plants no longer serve as food or medicine in Guam or Kii-Japan, respectively, these elegant but endangered Jurassic-age gymnosperms are used today on occasion to mark the entrances of important places (certain universities, hotels, hospitals and cemeteries, among others, in Japan and beyond). The Japanese Sago Palm (C. revoluta) also finds widespread acceptance abroad as an infertile ornamental plant in the garden or home, which results in occasional reports of acute hepatic poisoning in dogs that eat the toxic leaves. ${ }^{50}$ Livestock (cows, goats) that graze on the leaves of neurotoxic cycads in the extreme southern Nansei Islands of Japan and in Australia develop a poorly defined neuromuscular disease with spinal cord tract degeneration (neurocycadism). ${ }^{51,52}$ Neurocycadism $^{53}$ can be reproduced in goats fed cycasin, ${ }^{54}$ but the condition of the brain and eyes of such animals has never been reported. Based on the foregoing, it is of interest to examine the retina, brain and spinal cord of the offspring of cows and goats that develop experimental neurocycadism while pregnant. Controlled experimental studies are also needed to compare the toxic effects of L-BMAA and cycasin/MAM on the developing retina and cerebellum of laboratory animals and to explore the underlying molecular mechanisms and long-term outcome of the resulting tissue dysplasia.

\section{Conclusion}

Cerebellar abnormalities and a linear retinopathy are described in Guamanians and Kii-Japanese with ALS/ PDC, which is strongly associated with exposure to cycad neurogenotoxins, notably MAM. Medical knowledge of the use of cycad seed in food (Guam) and medicine (Kii-Japan), and their association with ALS/PDC dates from the $1960 \mathrm{~s}^{47,55,56}$ and $1980 \mathrm{~s}$, respectively. ${ }^{48,57}$ Reports of the experimental effects of MAM on the developing retina and cerebellum began to appear in the late 1960s. ${ }^{19-28,22-32}$ However, over the course of ensuing decades, experimentalists who studied the genotoxic effects of MAM on the retina and cerebellum were apparently unaware of relevant clinical literature on ALS/PDC, and biomedical investigators studying these structures in the human neurodegenerative disorder did not draw on the experimental findings.

\section{Summary}

The unique retinal and cerebellar pathology associated with Guam and Japanese cases of Western Pacific amyotrophic lateral sclerosis and parkinsonism-dementia (ALS/PDC) is proposed here to represent persistent retinal and cerebellar dysplasia acquired in utero from maternal exposure in food or medicine to cycasin, a neuroteratogen and probable principal environmental cause of Western Pacific ALS/PDC. 


\section{Acknowledgment}

Dr. John C. Steele is thanked for sharing the results of his extensive studies of Guam ALS/PDC and the retinopathy (Figure 1, left) associated therewith. Valerie Palmer and Glen Kisby are thanked for discussion.

\section{Disclosure}

The author has no financial, general, or institutional competing interests. The author had full access to all study data, takes full responsibility for the accuracy of the data analysis, and had total authority over manuscript preparation and the decision to submit the manuscript to Eye and Brain. Personal research referenced in this review was supported by grants from the National Institutes of Health: U19ES011384and P42ES010338.

\section{References}

1. Slusher MM, Holland WD, Weaver RG, Tyler ME. Ophthalmomyiasis interna posterior subretinal tracks and intraocular larvae. Arch Ophthalmol. 1979;97:885-887. doi:10.1001/archopht.1979.01020010443 008

2. Hira NK, Marciniak MM, Penner SL. Ophthalmomyiasis interna posterior and pigmentary retinopathy of Guam. J Am Optom Assoc. 1997;68:452-458.

3. Cox T, McDarby JV, Lavine L, et al. A retinopathy on Guam with high prevalence in lytico-bodig. Ophthalmology. 1989;96:1731-1735. doi:10.1016/S0161-6420(89)32656-X

4. Campbell RJ, Steele JC, Cox TA, et al. Pathological findings in the retinal pigment epitheliopathy associated with the amyotrophic lateral sclerosis/parkinsonism-dementia complex of Guam. Ophthalmology. 1993;100:37-42. doi:10.1016/S0161-6420(93)31696-9

5. Hanlon SD, Steele JC. An unusual retinal pigment epitheliopathy endemic to the island of Guam. Optom Vis Sci. 1993;70:854-859. doi:10.1097/00006324-199310000-00014

6. Steele JC, Wresch RR, Hanlon SD, et al. A unique retinopathy is associated with the amyotrophic lateral sclerosis/parkinsonism-dementia complex of Guam. Mov Disord. 2015;30:1271-1275. doi:10.1002/mds. 26264

7. Kokubo Y, Ito K, Kuzuhara S. Ophthalmomyiais-like pigmentary retinopathy in ALS/PDC in the Kii peninsula of Japan. Neurology. 2003;60:1725-1726. doi:10.1212/01.WNL.0000061487.16841.72

8. Kokubo Y, Ito K, Fukunaga T, et al. Pigmentary retinopathy of ALS/ PDC in Kii. Ophthalmology. 2006;113:2111.e1-2. doi:10.1016/j. ophtha.2006.07.002

9. Kokubo Y. Clinical aspects, imaging and neuropathology of Kii ALS/ PDC. Rinsho Shinkeigaku. 2007;47:966-969.

10. Tao Z, Wang Y, Yu S, et al. Hookworm in the eye. Lancet Infect Dis. 2018;18:582. doi:10.1016/S1473-3099(18)30097-5

11. Steele JC. The association of linear retinal pigment epitheliopathy (LRPE) and the parkinsonism dementia complex of Guam and Japan (ALS/PDC) 2002 - 2008. A final progress report to the board of directors and scientific advisory board of the society for cure PSP. 2008.

12. Schafer KA, Render JA. Toxicologic pathology of the eye: alterations of the lens and posterior segment. In: Weir AB, Collins M, editors Assessing Ocular Toxicology in Laboratory Animals. New York: Springer-Humana;2013:219-57. See: Veterian Key. Available from https:/veteriankey.com/toxicologicpathology-of-the-eye-alterationsof-the-lens-and-posterior-segment/\#CR70. Accessed April 20, 2020.
13. Agarwal N, Pantola CA, Gupta P, Agarwal A. Retinal dysplasia. A mimic of malignant ocular pathology. $J$ Clin Diagn Res. 2011;5:367-368.

14. Ramsey DT, Ewart SL, Render JA, Cook CS, Latimer CA. Congenital ocular abnormalities of Rocky Mountain Horses. Vet Ophthalmol. 1999;2:47-59. doi:10.1046/j.1463-5224.1999.00050.x

15. Spencer PS, Palmer VS, Kisby GE. Seeking environmental causes of neurodegenerative disease and envisioning primary prevention. Neurotoxicology. 2016;56:269-283. doi:10.1016/j.neuro.2016.03.017

16. Jackowiak E, Stewart B, Lorincx M ALS-like disorders of the Western Pacific. Medlink Neurology. 2019. Available from: https://www.medlink. com/article/als-like_disorders_of_the_western_pacific\#S4. Accessed June 12, 2020.

17. Kisby GE, Moore H, Spencer PS. Animal models of brain maldevelopment induced by cycad plant genotoxins. Birth Defects Res C Embryo Today. 2013;99:247-255. doi:10.1002/bdrc.21052

18. Karlsson O, Berg C, Brittebo O, Lindquist NG. Retention of the cyanobacterial neurotoxin $\beta-\mathrm{N}$-methylamino-l-alanine in melanin and neuromelanin-containing cells-a possible link between Parkinson-dementia complex and pigmentary retinopathy. Pigment Cell Melanoma Res. 2009;22:120-130. doi:10.1111/j.1755-148X.20 08.00508.x

19. Santucci S, Zsürger N, Chabry J. $\beta$-N-methylamino-l-alanine induced in vivo retinal cell death. $J$ Neurochem. 2009;109:819-825. doi:10.1111/j.1471-4159.2009.06022.x

20. Román GC. Neuroepidemiology of amyotrophic lateral sclerosis: clues to aetiology and pathogenesis. J Neurol Neurosurg Psychiatry. 1996;61:131-137. doi:10.1136/jnnp.61.2.131

21. Borenstein AR, Mortimer JA, Schofield E, et al. Cycad exposure and risk of dementia, MCI, and PDC in the Chamorro population of Guam. Neurology. 2007;68:1764-1771. doi:10.1212/01.wnl.0000262 $027.31623 . \mathrm{b} 2$

22. Spatz M, Dougherty WJ, Smith DWE. Teratogenic effects of methylazoxymethanol. Proc Soc Exp Biol Med. 1967;124:476-478. doi:10.3181/00379727-124-31767

23. Spatz M, Laqueur GL. Transplacental chemical induction of microcephaly in two strains of rats. I. Proc Soc Exp Biol Med. 1968;129:705-710. doi:10.3181/00379727-129-33404

24. Nagata Y, Matsumoto H. Studies on methylazoxymethanol: methylation of nucleic acids in the fetal rat brain. Proc Soc Exp Biol Med. 1969;132:383-385. doi:10.3181/00379727-132-34220

25. Matsumoto H, Spatz M, Laqueur GL. Quantitative changes with age in the DNA content of methylazoxymethanol-induced microencephalic rat brain. J Neurochem. 1972;19:297-306. doi:10.1111/j.14714159.1972.tb01339.x

26. Johnston MV, Grzanna R, Coyle JY. Methylazoxymethanol treatment of fetal rats results in abnormally dense noradrenergic innervation of neocortex. Science. 1979;203:369-371. doi:10.1126/ science. 32620

27. Cattabeni F, Di Luca M. Developmental models of brain dysfunctions induced by targeted cellular ablations with methylazoxymethanol. Physiol Rev. 1997;77:199-215. doi:10.1152/physrev.1997.77.1.199

28. Eiden LE, Latker C, Zatz M. Retinal toxicity of methylazoxymethanol acetate is developmentally specific. Dev Brain Res. 1981;1:425-428. doi:10.1016/0165-3806(81)90080-8

29. Fushimi K, Hirono I. Induction of retinal disorder with cycasin in newborn mice and rats. Acta Path Jap. 1972;23:307-314.

30. Hirono I. Carcinogenicity and neurotoxicity of cycasin with special reference to species differences. Fed Proc. 1972;31:1493-1499.

31. Haddad R, Rabe A. Use of the ferret in experimental neuroteratology: cerebral, cerebellar, and retinal dysplasias. In: Persaud TVN, editor. Neural and Behavioural Teratology Baltimore: Advances in the Study of Birth Defects. Vol. 4. Uni Park Press; 1980:45-62.

32. Latker $\mathrm{CH}$, Eide LE, Zatz M. The effect of methylazoxymethanol acetate (MAM) on the developing rat retina. Exp Eye Res. 1982;35:351-361. doi:10.1016/0014-4835(82)90098-7 
33. Wilke DA. Disease of the ocular posterior segment. In: Gilger BC, editor. Equine Ophthalmology. 2nd ed. New York: Elsevier; 2011.

34. Jones M, Yang M, Mickelsen O. Effects of methylazoxymethanol glucoside and methylazoxymethanol acetate on the cerebellum of the postnatal Swiss albino mouse. Fed Proc. 1972;31:1508-1511.

35. Lai H, Quock RM, Makous W, et al. Methylazoxymethanol acetate: effect of postnatal injection on brain amines and behavior. Pharmacol Biochem Behav. 1978;8:251-257. doi:10.1016/0091-3057(78)90312-X

36. Haddad R, Rabe A, Wen G, et al. Transplacental induction of structural and function abnormalities of the retina in carnivores. J Neuropathol Exp Neurol. 1978;37:621. doi:10.1097/00005072197809000-00161

37. Srivenugopal KS, Yuan XH, Friedman HS, Ali-Osman F. Ubiquitination-dependent proteolysis of O6-methylguanine-DNA methyltransferase in human and murine tumor cells after inactivation with O6-benzylguanine or 1,3-bis(2-chloroethyl)-1-nitrosourea. Biochemistry. 1996;35:1328-1334. doi:10.1021/bi9518205

38. Kisby GE, Olivas A, Park T, et al. DNA repair modulates the vulnerability of the developing brain to alkylating agents. DNA Repair. 2009;8:400-412. doi:10.1016/j.dnarep.2008.12.002

39. Meira LB, Moroski-Erkul CA, Green SL, et al. Aag-initiated base excision repair drives alkylation-induced retinal degeneration in mice. Proc Nat Acad Sci. 2009;106:88-93. doi:10.1073/pnas.0807030106

40. Shimada M, Langman J. Repair of the external granular layer of the hamster cerebellum after prenatal and postnatal administration of methylazoxymethanol. Teratology. 1970;3:119-134. doi:10.1002/ tera. 1420030204

41. Yamanaka H, Obata K. Displaced granule cells in the molecular layer of the cerebellar cortex in mice treated with methylazoxymethanol. Neurosci Lett. 2004;358:132-136. doi:10.1016/j.neulet.2003.12.108

42. Hartkop TH, Jones MZ. Methylazoxymethanol-induced aberrant Purkinje cell dendritic development. J Neuropathol Exp Neurol. 1977;36:519-532. doi:10.1097/00005072-197705000-00009

43. Schwartzkroin PA, Wenzel HJ. Are developmental dysplastic lesions clastogenic? Epilepsia. 2012;53(Suppl 1):35-44. doi:10.1111/j.15281167.2012.03473.x

44. Shiraki H, Yase Y. Amyotrophic lateral sclerosis in Japan. In: Vinken PJ, Bruyn GW, editors. System Disorders and Atrophy, Part 2. Handbook of Clinical Neurology. Vol. 22. Amsterdam: North Holland Publishing Co; 1975:353-419.

45. Morimoto S, Hatsuta H, Kokubo Y, et al. Unusual tau pathology of the cerebellum in patients with amyotrophic lateral sclerosis /parkinsonism-dementia complex from the Kii Peninsula, Japan. Brain Pathol. 2018;28:287-291. doi:10.1111/bpa.12500
46. Laure-Kamionowska M, Maślińska D. Cerebellar cortical neurons misplaced in the white matter due to disturbed migration during development of human brain. Folia Neuropathol. 2011;49:282-294.

47. Whiting MG. Toxicity of Cycads. Implications for Neurodegenerative Diseases and Cancer. Transcripts of Four Cycad Conferences February 2, 1962 (First), August 17, 1962 (Second), April 15, 1965 (Fourth) and April 24-25, 1967 (Fifth). New York: Third World Medical Research Foundation; 1988.

48. Spencer PS, Palmer VS, Kihira T, et al. Kampō medicine and Muro disease (Amyotrophic Lateral Sclerosis and Parkinsonism-Dementia Complex). eNeurologicalSci. 2020;18:100230. doi:10.1016/j.ensci. 2020.100230

49. Garruto RM, Gajdusek C, Chen KM. Amyotrophic lateral sclerosis among Chamorro migrants from Guam. Ann Neurol. 1980;8:612-619. doi: $10.1002 /$ ana.410080612

50. Fatourechi L, DelGiudice LA, Sookhoo N. Sago palm toxicosis in dogs. Compend Contin Edu Vet. 2013;35(4):e1-8.

51. Anon. Zamia staggers in cattle. Available from: https://www.daf.qld. gov.au/business-priorities/biosecurity/animalbiosecurity-welfare/ani mal-health-pests-diseases/protect-your-animals/poisonings-of-livestock /zamiastaggers-in-cattle. Accessed June 11, 2020.

52. Yasuda N, Shimuzu T. Cycad poisoning in cattle in Japan: studies on spontaneous and experimental cases. J Toxicol Sci. 1998;23:126-128. doi:10.2131/jts.23.SupplementII_126

53. Spencer PS, Dastur DK. Neurolathyrism and neurocycadism. In: Dastur DK, Shahani M, Bharucha EP, editors. Neurological Sciences: An Overview of Current Problems. Section VI. Tropical Neurology and Neurotoxicology New Dehli, Interprint; 1989:309-318.

54. Shimuzu T, Yasuda N, Kono I, et al. Hepatic and spinal lesions in goats chronically intoxicated with cycasin. Nihon Juigaku Zasshi. 1986;48:1291-1295. doi:10.1292/jvms1939.48.1291

55. Kurland LT. Introductory Remarks to "Proceedings of the Third Conference on the Toxicity of Cycads". In: Fed Proc. Vol. 23. 1964:1337-1339.

56. Kurland LT. An appraisal of cycad and the etiology of amyotrophic lateral sclerosis on Guam. In: Fed Proc. Vol. 31. 1972:1540-1542.

57. Spencer PS, Ohta M, Palmer VS. Cycad use and motor neurone disease in Kii Peninsula of Japan. Lancet. 1987;330:1462-1463. doi:10.1016/S0140-6736(87)91159-7
Eye and Brain

\section{Publish your work in this journal}

Eye and Brain is an international, peer-reviewed, open access journal focusing on clinical and experimental research in the field of neuroophthalmology. All aspects of patient care are addressed within the journal as well as basic research. Papers covering original research, basic science, clinical and epidemiological studies, reviews and

Submit your manuscript here: https://www.dovepress.com/eye-and-brain-journal evaluations, guidelines, expert opinion and commentary, case reports and extended reports are welcome. The manuscript management system is completely online and includes a very quick and fair peerreview system, which is all easy to use. Visit http://www.dovepress. com/testimonials.php to read real quotes from published authors. 